\title{
PENGARUH PENGGUNAAN ZEOLIT SEBAGAI BAHAN PENGGANTI SEBAGIAN SEMEN TERHADAP KUAT TEKAN PAVING BLOCK KONVENSIONAL
}

\author{
Agung Rizki Pratomo ${ }^{1)}$, Fepy Supriani ${ }^{2)}$, Agustin Gunawan ${ }^{3)}$ \\ ${ }^{122) 3)}$ Program Studi Teknik Sipil, Fakultas Teknik UNIB, J1. W. R. Supratman, \\ Kandang Limun, Bengkulu 38371, Telp. (0736)344087 \\ e-mail: fepy_ilham@yahoo.co.id
}

\begin{abstract}
Abstrak
Kandungan $\mathrm{SiO}_{2}$ yang terdapat pada zeolit melatar belakangi penelitian ini. Tujuan penelitian ini untuk mengetahui pengaruh zeolit sebagai bahan pengganti semen pada pembuatan paving block berumur 14 hari dengan menggunakan metode konvensional terhadap kuat tekan paving block. Pembuatan dan pengujian benda uji menggunakan SNI 03-06-1996. Benda uji berbentuk kubus dengan ukuran sisi $\pm 5 \mathrm{~cm}$ yang terdiri dari paving block normal dan 6 variasi dengan jumlah 5 benda uji setiap variasi. Keseluruhan benda uji berjumlah 35 benda uji. Penggantian variasi zeolit yang digunakan yaitu $2,5 \%, 5 \%, 7,5 \%, 10 \%, 12,5 \%$, dan $15 \%$ terhadap berat semen. Nilai kuat tekan paving block normal sebesar 15,64 MPa. Hasil pengujian kuat tekan mengalami peningkatan hanya terjadi pada variasi penggantian zeolit 2,5\% sebesar $6,28 \%$ terhadap paving block normal. Hasil pengujian kuat tekan mengalami penurunan terbesar pada variasi penggantian zeolit 15\% sebesar 39,05\% terhadap paving block normal.
\end{abstract}

Kata kunci : paving block, zeolit, kuat tekan

\begin{abstract}
This research was motivated by the contained $\mathrm{SiO}_{2}$ in zeolite. The purpose of this research was to know the zeolite effect as a substitute of cement in constructing 14 days paving block material which used conventional method toward the compressive strength of paving block. This research used SNI 03-06-1996 in constructing and testing the materials. The material was cube shaped with $\pm 5 \mathrm{~cm}$ size which consists of normal paving block and 6 variations with 5 specimens of each variation. Total of specimen were 35. Substitute of zeolite variations used $2,5 \%, 5 \%, 7,5 \%, 10 \%, 12,5 \%$, and $15 \%$ on the weight of cement. The result of compressive strength of normal paving block is 15,64 MPa. The result of compressive strength test had increased in the variation of 2,5\% zeolite substitute by 6,28\% normal paving block. The result of compressive strength test results showed the greatest decrease in variation of $15 \%$ zeolite replacement by 39,05\% against normal paving block.
\end{abstract}

Keywords: paving block, zeolit, compressive strength

\section{PENDAHULUAN}

Paving block adalah suatu komposisi bahan bangunan yang terbuat dari campuran semen portland atau bahan perekat hidrolis sejenisnya, air, dan agregat dengan atau tanpa bahan tambahan lainnya (SNI 030691-1996). Paving block harus memenuhi kualitas sebagai bahan bangunan yang digunakan sebagai pelapis perkerasan jalan. Kekuatan tekan merupakan salah satu karakteristik kualitas yang harus dimiliki paving block. Semakin tinggi kuat tekan, maka kualitas paving block semakin baik (Muliyasih, 2011). 
Paving block umumnya dibuat dengan panjang antara 200-250 mm dan lebar antara 100-112 mm. Ketebalan paving block yang sering digunakan berkisar antara 60-100 mm (Andre, 2012). Paving block sudah banyak digunakan di Indonesia seperti halaman rumah, tempat parkir, dan perkerasan jalan. Metode pembuatan paving block yang banyak digunakan umumnya dengan metode konvesional yaitu menggunakan alat cetak sederhana dengan harga relatif murah.

Zeolit merupakan suatu senyawa alumina silika terhidrasi yang mengandung kation atau alkali tanah (Poerwadi, dkk, 2014). Unsur utama pembentuk zeolit adalah $\mathrm{SiO} 2$ yang merupakan salah satu unsur pembentuk semen. Komposisi kimia zeolit alam dapat dilihat pada Tabel 1 .

Tabel 1. Komposisi Kimia Zeolit Alam

\begin{tabular}{|l|c|}
\hline Komposisi kimia & Persentase (\%) \\
\hline Silikon Dioksida $\left(\mathrm{SiO}_{2}\right)$ & 53,23 \\
\hline $\begin{array}{l}\text { Alumunium Oksida } \\
\left(\mathrm{Al}_{2} \mathrm{O}_{3}\right)\end{array}$ & 10,28 \\
\hline Ferri Oksida $\left(\mathrm{Fe}_{2} \mathrm{O}_{3}\right)$ & 4,84 \\
\hline Kalsium Oksida $(\mathrm{CaO})$ & 27,69 \\
\hline $\begin{array}{l}\text { Magnesium Oksida } \\
(\mathrm{MgO})\end{array}$ & 1,59 \\
\hline
\end{tabular}

Sumber: Setiadi dan Pertiwi, 2007

Semen memiliki komposisi utama kalsium oksida $(\mathrm{CaO})$ sebanyak 60-65\%, silika oksida $\left(\mathrm{SiO}_{2}\right)$ 20-24 \% (Marzuki, 2009). Berdasarkan kemiripan unsur yang dimiliki semen dan zeolit, maka pemanfaatan zeolit sebagai bahan pengganti semen pada paving block diharapkan dapat menjadi alternatif untuk mendapatkan biaya yang murah dengan mutu yang baik.

Penelitian ini bertujuan untuk mengetahui pengaruh penggunaan zeolit sebagai bahan pengganti semen terhadap kuat tekan paving block berumur 14 hari. Benda uji bebentuk balok dengan ukuran $20 \mathrm{~cm}$ x $10 \mathrm{~cm}$ x $6 \mathrm{~cm}$. Pada saat dilakukan pengujian, paving block dipotong berbentuk kubus dengan ukuran sisi $\pm 5 \mathrm{~cm}$ sesuai dengan SNI 03-06-1996 dengan persentase penggantian zeolit sebanyak $2,5 \%, 5 \%, 7,5 \%, 10 \%, 12,5 \%$, dan $15 \%$ terhadap berat semen.

\section{METODE PENELITIAN}

Bahan utama dalam pembuatan paving block normal adalah semen, pasir dan air. Selanjutnya, sebagian semen diganti dengan zeolit dengan komposisi 2,5\%, 5\%, 7,5\%, $10 \%, 12,5 \%$, dan $15 \%$. Persiapan bahan meliputi:

1. Zeolit

Zeolit yang digunakan berasal dari daerah Desa Kancing, Kecamatan Karang Tinggi Kabupaten Bengkulu Tengah. Zeolit dibersihkan dari kotoran yang menempel. Zeolit ditumbuk menjadi halus dan diayak menggunakan ayakan no.100. Zeolit kemudian diaktivasi dengan cara dipanaskan di dalam oven dengan temperatur $110^{\circ} \mathrm{C}$ selama 24 jam. Batu zeolit yang digunakan dapat dilihat pada Gambar 1 dan zeolit lolos saringan 100 dapat dilihat pada Gambar 2.

2. Agregat halus (pasir)

Agregat halus yang digunakan diambil dari lokasi pabrik pembuatan paving block berasal dari daerah Selolong Bengkulu Utara.

3. Semen

Semen yang digunakan adalah semen PCC sesuai SNI 15-7064-2004.

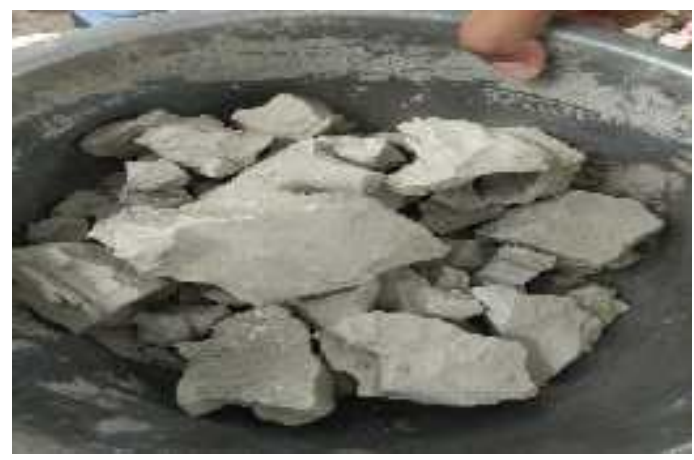

Gambar 1. Batu Zeolit Alam 


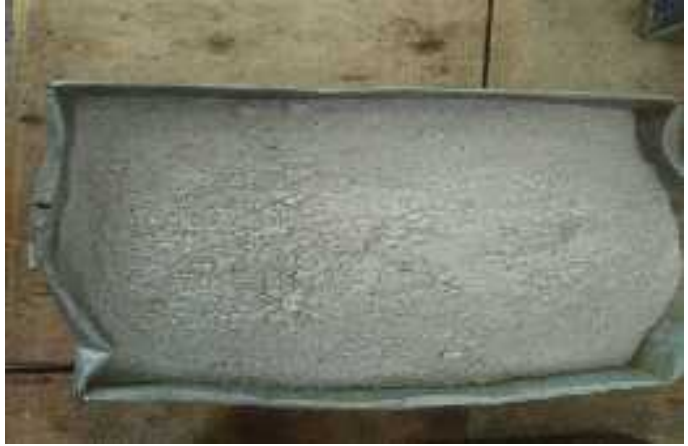

Gambar 2. Zeolit Lolos Saringan no.100

Penelitian menggunakan zeolit sebagai bahan pengganti semen dalam pembuatan paving block. Variasi persentase zeolit yang digunakan adalah 2,5\%, 5\%, 7,5\%, 10\%, $12,5 \%$, dan $15 \%$ dari berat semen. Setiap variasi dibuat 5 sampel dengan menggunakan pasir selolong. Pengaruh variasi persentase penggunaan zeolit sebagai pengganti semen ini diketahui berdasarkan uji kuat tekan paving block pada umur umur 14 hari. Paving block berbentuk balok dengan ukuran $20 \mathrm{~cm}$ x $10 \mathrm{~cm}$ x $6 \mathrm{~cm}$. Pada saat dilakukan pengujian, paving block dipotong berbentuk kubus dengan ukuran sisi $\pm 5 \mathrm{~cm}$ sesuai dengan SNI 03-06-1996.

Pembuatan paving block dilakukan secara konvensional. Metode konvensional paling banyak digunakan oleh masyarakat dan lebih dikenal dengan metode gablokan. Semakin kuat tenaga orang yang mengerjakan, maka akan semakin padat dan kuat paving block yang dihasilkan. Pekerja akan cepat kelelahan karena proses pemadatan yang berulang, Pamungkas dan Hairunnisa (2007).

Perawatan benda uji dilakukan selama 12 hari dengan perendaman di dlam air. Selanjutnya dilakukan pengujian kuat tekan paving block. Rumus perhitungan untuk mencari kuat tekan paving block berdasarkan SNI 03-0691-1996 adalah:

$$
\mathrm{F}_{\mathrm{PB}}^{\prime}=\frac{\mathrm{P}}{\mathrm{A}}
$$

Keterangan :

$\mathrm{F}^{\prime}{ }_{\mathrm{PB}}=$ Kuat Tekan Paving Block $(\mathrm{MPa})$

$\mathrm{P}=$ Beban Tekan Paving Block $(\mathrm{N})$

A $=$ Luas Bidang Tekan $\left(\mathrm{mm}^{2}\right)$

Hasil pencetakan paving block persegi empat terlihat pada Gambar 3, sedangkan hasil pemotongan paving block $5 \mathrm{~cm} \times 5 \mathrm{~cm}$ untuk ukuran standar pengujian (Gambar 4).

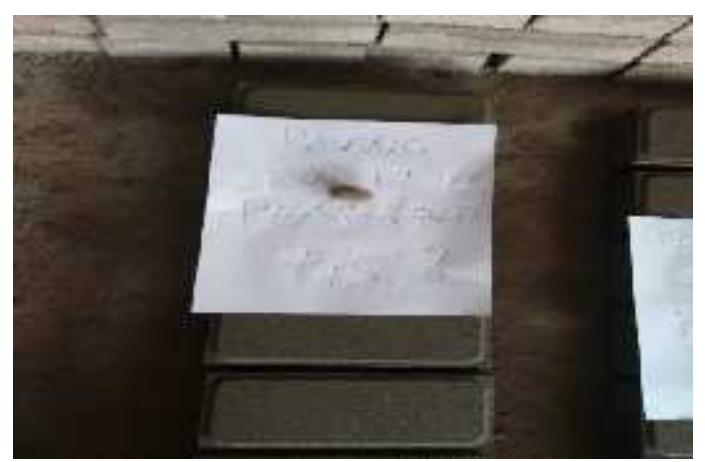

Gambar 3. Hasil Pencetakan Paving Block

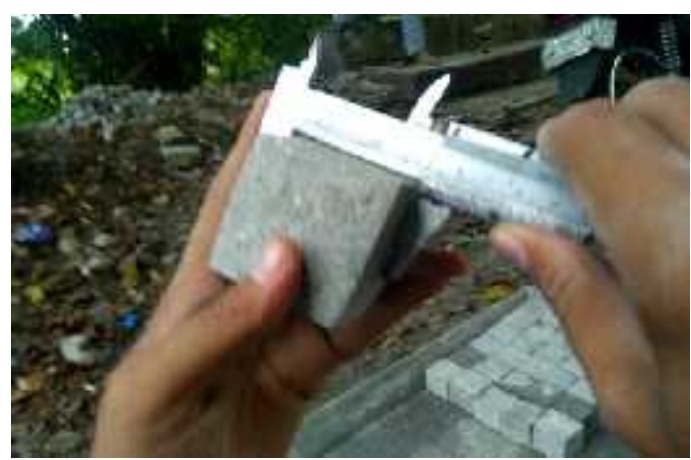

Gambar 4. Benda Uji Paving Block

\section{HASIL DAN PEMBAHASAN}

Semua hasil pengujian bahan pembentuk paving block telah memenuhi syarat agregat yang normal. Hasil data yang diperoleh pada tahapan pemeriksaan bahan pembentuk paving block yaitu pasir dapat dilihat pada Tabel 2.

Tabel 2. Hasil Pemeriksaan Pasir

\begin{tabular}{|c|l|c|}
\hline No. & \multicolumn{1}{|c|}{ Jenis Pengujian } & $\begin{array}{c}\text { Pasir } \\
\text { Selolong }\end{array}$ \\
\hline 1 & Kadar Air (\%) & 2,39 \\
\hline 2 & Kadar Lumpur(\%) & 0,77 \\
\hline 3 & BJ(SSD) & 2,81 \\
\hline 4 & Berat Isi (kg/m3) & 1,4 \\
\hline
\end{tabular}


Pengujian kuat tekan paving block dimaksudkan untuk mengetahui kekuatan tekan paving block, dimana kuat tekan beton dilihat dari berapa besar beban yang ditahan untuk setiap satuan luas. Hasil pengujian berdasarkan rumus 1 .

Kuat tekan sampel paving block diuji pada umur 14 hari. Sampel tidak menggunakan ukuran paving block yang sebenarnya, tetapi dipotong dengan ukuran $5 \times 5 \mathrm{~cm}$ sesuai standar pengujian. Tahapan pengujian ini dilakukan berdasarkan SNI 03-0691-1996. Data kuat tekan rata-rata yang disajikan pada Tabel 3 dan Gambar 5 telah dilakukan perhitungan standar deviasi serta masuk dalam batas atas dan batas bawah.

Tabel 3. Data Nilai Rata-Rata Kuat Tekan Paving Block.

\begin{tabular}{|l|c|c|}
\hline \multicolumn{1}{|c|}{ Kode } & Variasi & $\begin{array}{c}\text { Kuat Tekan } \\
\text { Rata-Rata (MPa) }\end{array}$ \\
\hline PBZ 0\% & $0 \%$ & 15,64 \\
\hline PBZ-2,5\% & $2,5 \%$ & 16,62 \\
\hline PBZ -5\% & $5 \%$ & 15,38 \\
\hline PBZ -7,5\% & $7,5 \%$ & 12,64 \\
\hline PBZ -10\% & $10 \%$ & 12,69 \\
\hline PBZ -12,5\% & $12,5 \%$ & 9,70 \\
\hline PBZ -15\% & $15 \%$ & 9,53 \\
\hline
\end{tabular}

Keterangan:

PBZ = Paving Block zeolit.

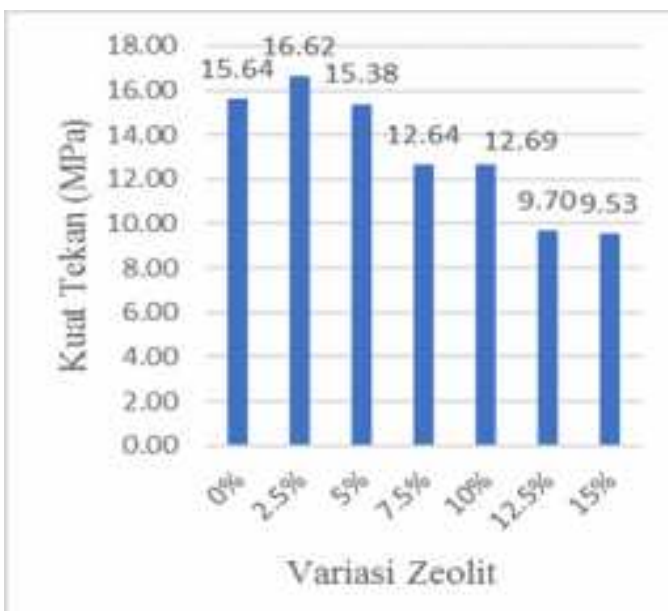

Gambar 5. Grafik Nilai Rata-Rata Kuat Tekan Paving Block
Data hasil pengujian hanya mengalami peningkatan pada variasi penggantian zeolit sebesar 2,5\% terhadap paving block normal. Nilai kuat tekan pada variasi penggantian zeolit 2,5\% sebesar 16,62 MPa. Selanjutnya kuat tekan paving block menurun dengan bertambahnya persentase penambahan zeolit. Variasi $15 \%$ mengalami penurunan terbesar terhadap paving block normal. Nilai kuat tekan pada variasi penggantian zeolit $15 \%$ sebesar 9,53 MPa.

Data persentase selisih nilai rata-rata kuat tekan paving block dapat dilihat pada Gambar 6 dan Tabel 4.

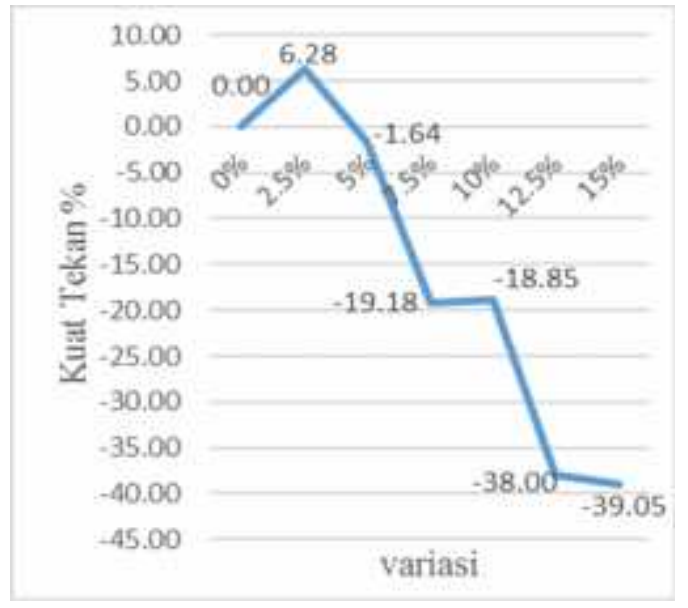

Gambar 6. Grafik Persentase Selisih Nilai Kuat Tekan Rata-Rata terhadap Paving Block Normal.

Tabel 4. Selisih Nilai Rata-Rata Kuat Tekan Paving Block

\begin{tabular}{|l|c|c|}
\hline Kode & Variasi & $\begin{array}{c}\text { Selisih Nilai } \\
\text { Kuat Tekan dari } \\
\text { Paving Block } \\
\text { Normal (\%) } \\
\text { Peningkatan (+) } \\
\text { Penurunan (-) }\end{array}$ \\
\hline PBZ 0\% & $0 \%$ & 0 \\
\hline PBZ-2,5\% & $2,5 \%$ & 6,28 \\
\hline PBZ -5\% & $5 \%$ & $-1,64$ \\
\hline PBZ -7,5\% & $7,5 \%$ & $-19,18$ \\
\hline PBZ -10\% & $10 \%$ & $-18,85$ \\
\hline PBZ -12,5\% & $12,5 \%$ & $-38,00$ \\
\hline PBZ -15\% & $15 \%$ & $-39,05$ \\
\hline
\end{tabular}


Keterangan:

PBZ = Paving Block zeolit.

PBZ 0\% adalah mewakili paving block normal tanpa penambahan zeolit. Beton normal dibuat sebagai pembanding untuk melihat kenaikan dan penurunan paving block akibat pergantian sebagian semen dengan zeolit.

Gambar 6 menunjukkan grafik penurunan dan kenaikan kuat tekan paving block dalam \%. Beton normal (0\% pergantian pasir) menjadi acuan. Nilai positif diatas 0 adalah trend kenaikan kuat tekan dan nilai negatif menunjukkan trend penurunan kuat tekan.

Persentase nilai kuat tekan paving block umur 14 hari pada penggantian zeolit dengan variasi $2,5 \%$ terjadi peningkatan dibandingkan terhadap kuat tekan paving block normal. Persentase peningkatan nilai kuat tekan terjadi pada variasi $2,5 \%$ yaitu sebesar $6,28 \%$. Trend penurunan kuat tekan beton akibat pergantian sebagian semen mulai terlihat pada pergantian $5 \%$ semen dengan zeolit. Penurunan siknifikan terlihat pada pergantian $7,5 \%$ sebesar $19,18 \%$, dan kembali turun siknifikan pada pergantian $12,5 \%$ sebesar $38 \%$. Persentase penurunan nilai kuat tekan terbesar yaitu pada variasi $15 \%$ sebesar $39,05 \%$.

Pergantian sebagian semen dengan zeolit pada komposisi tertentu pada penelitian ini hanya memberikan trend positif pada pergantian 2,5\%. Selanjutnya untuk pergantian lebih dari 2,5\% memberikan trend negatif berupa penurunan kuat tekan seiring dengan semakin besarnya persentasi penambahan zeolit.

Komposisi kalsium oksida dan silikon oksida yang dimiliki zeolit, meskipun memiliki kemiripan dengan semen belum mampu meningkatkan kuat tekan paving block dengan pergantian lebih banyak, Hal ini kemungkinan disebabkan perbedaan komposisi yang dominan. Berdasarkan teori diatas, semen memiliki komposisi utama kalsium oksida $(\mathrm{CaO})$ sebanyak $60-65 \%$, sedangkan zeolit kanduan CaOnya 27,69\%. Kandungan silicon oksida $\left(\mathrm{SiO}_{2}\right)$ pada semen adalah 20-24 \%, sedangkan pada zeolit $53,23 \%$. Secara teoritis kandungan $\mathrm{CaO}$ pada zeolit tidak bisa memenuhi komposisi pergantian, begitu sebaliknya $\mathrm{SiO}_{2}$ pada zeolit terlalu dominan sebagai pengganti semen.

\section{KESIMPULAN}

Kesimpulan yang dapat diambil dari hasil penelitian dan pengujian yang dilakukan antara lain:

1. Hasil kuat tekan rata-rata paving block pada umur 14 hari dengan menggunakan zeolit sebagai bahan pengganti semen pada variasi $0 \%, 2,5 \%, 5 \%, 7,5 \%, 10 \%$, $12,5 \%$, dan $15 \%$ secara berturut-turut adalah 15,64 $\mathrm{MPa}, 16,62 \mathrm{MPa}, 15,38$ $\mathrm{MPa}, 12,64 \mathrm{MPa}, 12,69 \mathrm{MPa}, 9,70 \mathrm{MPa}$, dan 9,53 MPa.

2. Persentase peningkatan kuat tekan paving block terhadap paving block normal hanya terjadi pada variasi $2,5 \%$ sebesar $6,28 \%$ dan mulai mengalami penurunan pada variasi $5 \%(1,64 \%), 7,5 \%(19,18 \%)$, $10 \%(18,85 \%), 12,5 \%(38 \%) 2$ dan $15 \%$ $(39,05 \%)$.

3. Penurunan terbesar pada variasi $15 \%$ sebesar $39,05 \%$.

\section{DAFTAR PUSTAKA}

Andre, 2012, Studi Sifat Mekanik Paving Block Terbuat dari Campuran Limbah Adukan Beton dan Serbuk Kerang, Fakultas Teknik Program Studi Teknik Sipil Universitas Indonesia, Jakarta.

Marzuki, I, 2009, Analisis Penambahan Additive Batu Gamping terhadap Kualitas Komposisi Kimia Semen Portland, Jurnal Chimica UNM. 
Muliyasih, S., 2011, Pembuatan Paving Block dengan Menggunakan Limbah Las Karbit sebagai Bahan Aditif dengan Perekat Limbah Padat Abu Terbang Batubara (fly ash) Pitu Labuhan Angin Sibolga, Jurnal Teknik Sipil.

Pamungkas, B., dan Hairunnisa, S., 2007, Komparasi Mutu Paving block antara Metode Mekanis dan Konvensional dengan Campuran Endapan Sampah, Universitas Diponegoro, Semarang.
Poerwadi, M.R., Zacoeb, A., dan Syamsudin, R., 2014, Pengaruh Penggunaan Mineral Lokal Zeolite Alam terhadap Karaakteristik SelfCompacting Concrete (SCC), Jurnal Teknik Sipil.

Setiadi, dan Pertiwi, A., 2007, Preparasi dan Karakteristik Zeolite Alam untuk Konversi Senyawa Abe menjadi Hidrokarbon, Jurnal Teknik Kimia.

SNI 03-0691-1996: Bata Beton (Paving block), Dewan Standardisasi Nasional, Jakarta. 